\title{
The Effects of State-Level Medicaid Coverage on Family Wealth
}

\author{
MARGOT JACKSON॰, CHINYERE AGBAI, AND EMILY RAUSCHER
}

Jointly financed by the federal government and the states, Medicaid represents the second largest form of public-sector investment in children. Research documents direct positive effects of Medicaid on children's well-being, but little is known about the effects of Medicaid expansions on the wealth of families with children. Using state variation in Medicaid access during the prenatal and infant period, linked to longitudinal data from the children of National Longitudinal Survey of Youth 79, we ask whether state-level Medicaid generosity is associated with family wealth among families with children and whether these effects vary by parental education and race-ethnicity. We find that greater state-level Medicaid access is associated with a larger total amount held in savings and retirement accounts, as well as in mortgages. These effects are largely driven by non-Hispanic white families, and those with more highly educated mothers.

Keywords: Medicaid, inequality, wealth, children

Since its creation in 1965, the federal Medicaid program has been a major provider of health insurance for low- and moderate-income families in the United States. Jointly financed by the federal government and the states, Medicaid currently represents the second largest form of public-sector investment in children, after K-12 education (Isaacs and Edelstein 2017). The form and size of Medicaid investments vary widely across states, given large differences in states' rules about eligibility levels, service coverage, payment mechanisms, and spending per enrollee. State-level indicators of Medicaid access thus provide a useful indicator of families' ac- cess to key resources necessary for healthy child development. Increased access to Medicaid may affect children both directly, via access to crucial health care, and indirectly by reducing family medical expenses, allowing them to increase their economic resources.

Research documents direct positive effects of state-level Medicaid coverage on short and longer-term outcomes for child and adult health (Currie and Gruber 1996; GoodmanBacon 2018; Miller and Wherry 2019). These effects are quite meaningful not only for children's health, but also for their broader educational progression and human capital

Margot Jackson is associate professor of sociology at Brown University, United States. Chinyere Agbai is a PhD student in sociology at Brown University, United States. Emily Rauscher is associate professor of sociology at Brown University, United States.

(C) 2021 Russell Sage Foundation. Jackson, Margot, Chinyere Agbai, and Emily Rauscher. 2021. “The Effects of State-Level Medicaid Coverage on Family Wealth." RSF: The Russell Sage Foundation Journal of the Social Sciences 7(3): 216-34. DOI: 10.7758/RSF.2021.7.3.10. Direct correspondence to: Margot Jackson at margotj@brown. edu, Brown University Department of Sociology, Box 1916, Providence RI 02912, United States.

Open Access Policy: RSF: The Russell Sage Foundation Journal of the Social Sciences is an open access journal. This article is published under a Creative Commons Attribution-NonCommercial-NoDerivs 3.0 Unported License. 
development. For example, Medicaid coverage can help families control child asthma, which can increase school attendance (Currie 2005). However, much less is known about the effects of state-level Medicaid access on the wealth of families with children. Increased access to Medicaid may affect children both directly, via access to crucial health care, and indirectly by reducing family medical expenses, allowing them to increase their economic resources. Greater wealth at the family level is important not only because it provides access to better nutrition and medical care, but also because wealth is positively linked to children's human capital development and educational attainment (Elliott, Destin, and Friedline 2011; Pfeffer 2018).

Despite its importance, wealth is the most unequally distributed economic resource, with the top 1 percent of wealth holders owning 36 percent of the wealth in the United States (Killewald, Pfeffer, and Schachner 2017; Saez and Zucman 2016; Stone et al. 2020). Moreover, centuries of policies and practices, including slavery, Jim Crow, racial terrorism, and ongoing predatory lending practices, have hampered the ability of nonwhites, and especially black families, to amass wealth (Du Bois 1935; Faber 2018; Freund 2007; Taylor 2019). As a result, wealth gaps are particularly large among families with children and across racial and ethnic groups (Gibson-Davis and Percheski 2018; Pfeffer 2018; Saez and Zucman 2016). By reducing out-ofpocket medical costs, greater state-level Medicaid access may facilitate the ability of families, the most socioeconomically disadvantaged families in particular, to increase their savings and assets more generally. Health and health care are fundamental for child development but can require substantial private spending and even debt (Hu et al. 2018). Any savings associated with Medicaid may in turn better allow families to directly invest in their children's development.

This article examines the effects of statelevel Medicaid access on family wealth. We use state variation in Medicaid access during the prenatal and infant period, driven by federal and state Medicaid expansions that increased access at different times across states in the 1980s. Linking these state-level measures to longitudinal data from the children of National Longitudinal Survey of Youth 79 (NLSY79-C), we ask two questions: First, is greater state-level Medicaid generosity positively associated with wealth among families with children? Second, do these effects vary by parental education and race-ethnicity? We find that, on average, greater state-level Medicaid access is associated with a larger total amount held in savings and retirement accounts, as well as in mortgages. These effects are largely driven by non-Hispanic white families, and those with more highly educated mothers.

\section{BACKGROUND}

Created in 1965 through the Social Security Amendments of 1965, Medicaid is a major provider of health insurance for low- and moderateincome families in the United States. Jointly financed by the federal government and the states, Medicaid represents the second largest form of government investment in children, after K-12 education (Isaacs and Edelstein 2017). Unlike some more "universalist" public investments, such as $\mathrm{K}-12$ public education, which serves children across income groups, Medicaid is a targeted investment toward low- and moderate-income families. The Medicaid program has also undergone several expansions at both the federal and state level over time, resulting in wide variation across place and time in eligibility levels, service coverage, payment mechanisms, and spending per enrollee.

When Medicaid was created in 1965, coverage for children and pregnant women was restricted to families receiving welfare benefits via the Aid to Families with Dependent Children (AFDC) program, consisting primarily of single-parent families with incomes below the poverty line. Many of the federal and state Medicaid expansions that have led to variation in eligibility and the timing of implementation across states have focused on pregnant women and children in the first year of life. Beginning in the 1980s, especially between 1987 and 1990 in response to a large national Medicaid expansion through the Omnibus Budget Reconciliation Act of 1986 (OBRA86), states began to expand coverage to include prenatal and infant care for two-parent families in AFDC, as well as families with incomes above the poverty line. 
In addition to federal expansions that increased access or benefits at different times across states, some states expanded Medicaid beyond federal minimums for benefit and coverage. This series of expansions between 1980 and the early 1990s meant that many states began to cover pregnant women and their infants if their family income was up to 185 percent of the poverty threshold, up from the previous maximum coverage at 79 percent of the poverty line before the expansion (Currie and Gruber 1996; Miller and Wherry 2019). Between 1984 and 1992, eligibility for Medicaid more than doubled among U.S. children, and almost one-third were eligible for enrollment by 1992 (Currie and Gruber 1996).

\section{Medicaid and Family Wealth}

Medicaid access could be associated with family wealth in several ways. First, increased coverage may be positively associated with households' wealth by freeing up funds that would otherwise be used for medical expenses, better enabling families to save money or purchase assets. This possibility may have become more likely after the OBRA86 expansion, when the vast majority of states ended their previous use of asset testing for determining Medicaid eligibility. Previously, Medicaid eligibility for pregnant women and infants had been tied to their AFDC eligibility, which involved asset testing to qualify. The asset test allowed "a home of any value, an automobile worth up to $\$ 1,500$, and any other real or personal property essential for day-to-day living worth up to $\$ 1,000$ " (Government Accountability Office 1987, 18). Income and asset limits for Supplemental Security Income (SSI), Medicaid through SSI eligibility, and those for the medically needy program were higher (Government Accountability Office 1987). In addition to expanding access based on income limits, OBRA86 also provided states with options to simplify the Medicaid eligibility process for pregnant women and infants. For example, states shortened application forms, out-stationed eligibility workers at provider sites, and expedited maternity-related applications (National Governors' Association 1990, 3). States also dropped the asset test required for Medicaid eligibility among pregnant women and infants. In 1990, "44 states no longer review clients' assets when determining eligibility for pregnant women and children" (National Governors' Association 1990, 3). The seven states that retained the asset test were California, Colorado, Illinois, Iowa, Missouri, North Dakota, and Texas. Additional states dropped the test over time: Colorado and Missouri by July 1990 and Illinois and Texas by July 1991. Beginning in 1992, some states (Nevada, Utah, and Arkansas) began reinstating asset tests for Medicaid eligibility among pregnant women or children (National Governors' Association 1992).

The elimination of asset testing as a condition for Medicaid enrollment among pregnant women and young children increased the possibility for participating families to build wealth. Greater access to Medicaid for low- and middle-income families may reduce the amount these families spend on out-of-pocket medical expenses, private insurance premiums, expensive copayments, or other directly purchased services. Although many pregnant women and young children who became eligible for Medicaid with the expansions were uninsured, more than a third were covered under private insurance plans (Cutler and Gruber 1996; Dubay and Kenney 1997), which typically have higher out-of-pocket costs for premiums and copayments. The ability to substitute public insurance for private insurance may therefore free up economic resources for some families, enabling them to save money or to purchase assets such as a home.

Among families who were uninsured, public insurance may also replace some degree of private spending. Research concerning the effects of Medicaid on consumption in the broader adult population demonstrates that increases in Medicaid access are associated with increases in spending on nondurable goods (Gruber and Yelowitz 1999), and that switching from private to public health insurance reduces spending on out-of-pocket medical care and health insurance costs (Shaefer, Grogan, and Pollak 2011). Among families with children, a study on the effects of State Children's Health Insurance Program (SCHIP, later CHIP) expansions in the late $1990 \mathrm{~s}$, which were targeted toward higher income families than the Medicaid expansions, shows that SCHIP coverage increases savings behavior among households 
with children (Leininger, Levy, and Schanzenbach 2010). Evidence on the effects of Medicaid expansions on the wealth of families with children is lacking, however.

Increases in Medicaid access may also reduce the debt held by families with children, both by reducing medical debt and by improving their ability to pay down existing debts from credit cards and other sources. Although surprisingly little research examines the effects of Medicaid on debt, evidence among adults suggests that Medicaid coverage reduces the likelihood of personal bankruptcy, as well as the prevalence of "medical divorces" intended to protect the assets of a healthy spouse when the other spouse has substantial medical bills (Gross and Notowidigdo 2011; Slusky and Ginther 2017). Results from an experimental Medicaid expansion program in Oregon demonstrate that Medicaid access significantly reduced the frequency of missed bill payments because of medical expenses (Finkelstein et al. 2012). In addition, research on the recent Medicaid expansion under the Affordable Care Act demonstrates that increased Medicaid access reduces the number of unpaid bills and the amount of debt sent to collection agencies ( $\mathrm{Hu}$ et al. 2018; Miller and Wherry 2019). However, these studies focus on the broader Medicaideligible population and not on families with children.

Despite reasons to expect a positive effect of Medicaid access on savings and wealth among families with children, it is also possible that the association is negative. Increased Medicaid access may reduce families' need to save in the presence of a new safety net, to the extent that low-resource families are able to save at all. Relatedly, families may prioritize short-term expenses, increasing consumption instead of savings for longer-term expenses. Some evidence suggests that Medicaid expansions are negatively associated with savings and wealth holdings among all households, and that these negative effects are especially strong when asset testing is in effect (see, for example, Gruber and Yelowitz 1999). Although the vast majority of states eliminated asset tests with Medicaid expansion, families may have believed asset testing remained in effect.

In sum, previous evidence on the Medicaid- eligible population offers mixed evidence and focuses on the general population rather than on families with children. It is plausible that higher Medicaid coverage should increase the ability of eligible families to save money or reduce debt via reduced out-of-pocket costs. It is also possible, however, that Medicaid access does not increase wealth because families may prioritize short-term expenses over savings. The little research on Medicaid expansions provides limited evidence of effects for families with children and offers a very short-term perspective on the effects of Medicaid.

\section{Variation by Education and Race-Ethnicity}

It is important to consider the possibility that Medicaid affects family wealth differently for groups by education and race-ethnicity because the composition of Medicaid participants is heterogeneous. For example, among Medicaidcovered births between 1999 and 2005, 30 percent of mothers had more than a high school education, 30 percent had a high school degree, and 40 percent had not graduated. About half were non-Hispanic black or Hispanic (Lloyd et al. 2018). In 2000, 38 percent of Medicaid or CHIP-covered children were non-Hispanic white, 32 percent were non-Hispanic black, and 25 percent were Hispanic; 62 percent of parents had more than a high school education (Coyer and Kenney 2013). In addition, wealth varies dramatically by education and race. Those with less education hold much less wealth than more educated families (Hartog and Oosterbeek 1998; Pfeffer, Danziger, and Schoeni 2013; Semyonov and Lewin-Epstein 2013). Racial gaps in wealth-especially black-white gaps-are also striking. As of 2016, white households hold almost ten times the wealth of black families, with whites holding $\$ 171,000$ to blacks' $\$ 17,600$, on average (Dettling et al. 2017). Racial wealth gaps are especially driven by differences in homeownership, which is the largest source of wealth for most Americans. Wealth gains associated with homeownership are much larger for white families than for black or Hispanic families, and whites are also more likely to be homeowners than renters (Collins and Margo 2001; Conley 1999; Killewald and Bryan 2016; National Low Income Housing Coalition 2020).

The relative socioeconomic disadvantage of 
less educated black and Hispanic families could mean that they are less able to increase savings with Medicaid access. Income is more likely to be unstable among adults with lower socioeconomic status (SES) (Hannagan and Morduch 2015; Kalleberg, Reskin, and Hudson 2000; Pew Charitable Trusts 2017), meaning that any savings associated with Medicaid may be used for short-term needs over longer-term savings. In addition, although sociohistorical forces have contributed significantly to contemporary racial-ethnic gaps in wealth, discrimination in housing and mortgage markets remains, and ongoing exclusion may make it harder for black and Latino families to build wealth even with the same savings as nonLatino white families (see Quillian, Lee, and Honoré 2020). Because of this, the benefits of Medicaid may be largest among more-educated and non-Hispanic white families, who are more likely to be in a position to save. Alternatively, increases in Medicaid may most strongly affect the behavior of less-educated and racial minority families, for whom saving may be a new possibility. Evaluations of other progressive policies that provide cash or in-kind transfers to low-resource families suggests that the benefits of these transfers are often largest among the most disadvantaged participants (GoodmanBacon 2018; Meyer 2010). These findings are consistent with the idea that Medicaid should affect the wealth of the most disadvantaged families the most, rather than providing additional benefits to highly educated and white participants.

\section{DATA}

Data from our study come from two sources. First, we measure family characteristics, including wealth, using data from the children of the National Longitudinal Survey of Youth 79 (NLSY79-C). The NLSY79 is a large, nationally representative sample of the family, social, and economic lives of approximately thirteen thousand men and women who were between fourteen and twenty-two years old at the time of the first interview in 1979. Until 1994, respondents were interviewed annually, and from then forward biennially. The NLSY-C is a survey of all children born to NLSY79 mothers. Beginning in 1986, mothers were interviewed biennially (and their children assessed) in an effort to measure family socioeconomic context and child development. To date, more than 11,500 children have been followed and assessed. Collectively, the data provide rich, longitudinal information on the economic circumstances and development of a large, nationally representative sample. Very few data sets include both high quality wealth data within the same families over time. NLSY data also include geographic identifiers and a large sample of young children, making it uniquely suited to answer questions about the effects of Medicaid expansions focused on mothers and young children.

We link NLSY-C data to longitudinal, statelevel data on Medicaid eligibility thresholds. Between 1987 and 1993, national increases in the income and age requirements for Medicaid eligibility among children and pregnant women were substantial. As Sarah Miller and Laura Wherry (2019) describe in detail, the proportion of women and infant who were eligible for Medicaid during pregnancy increased from 13 percent in 1979 to 44 percent by 1993 . These increases were implemented at different times across states, resulting in variation in Medicaid eligibility among otherwise similar women and children across time and place. We follow recent research and use simulated prenatal Medicaid eligibility calculated from changes in state prenatal Medicaid eligibility rules applied to a national sample of three thousand women from each year (Miller and Wherry 2019). ${ }^{1}$ This approach makes it more feasible to identify the implications of changes in Medicaid policy alone, distinct from other state-level policies or state-level economic or demographic characteristics. Because of the timing of expansions across the United States, we limit our NLSY-C analytic sample to the period between 1986 and 2000 .

\section{Measures}

In an effort to capture the numerous dimensions of family wealth, we examine multiple measures of assets and debts, in addition to total net worth. Net worth is a derived measure

1. We are grateful to Laura Wherry for sharing the annual simulated Medicaid eligibility measures. 
in the NLSY-C, which consists of adding the value of all household assets and subtracting household debt (Gruber and Yelowitz 1999; Orr 2003). Home value and mortgage are recorded for homeowners and reflect the total market value of the home and the amount owed on the property, respectively. Other debt captures the amount of any other kind of debt owed on the residential property. Savings records the amount held in savings. To create the accounts measure, we sum the amount held in four kinds of liquid assets: savings, certified deposits, investment retirement accounts (IRAs), and taxdeferred savings plans. Car value reflects the total market value of the respondent's vehicle, and car debt records how much is owed on the vehicle.

All wealth measures are collected at the family level and converted to 2018 dollars. Like income, wealth is a highly right-skewed measure of economic resources, with many families possessing zero or negative wealth, and the wealthiest families holding a disproportionately large share of assets. ${ }^{2}$ We follow previous research and use an inverse hyperbolic sine (IHS) transformation for all wealth measures (Friedline, Masa, and Chowa 2015). The IHS transformation can be expressed as

$$
\operatorname{IHS}(\text { wealth })=\log \left(\text { wealth }+\sqrt{\text { wealth }^{2}+1}\right) .
$$

Transforming wealth in this way has many benefits, including adjusting for skewness and retaining 0 and negative values. The IHS transformation is a useful alternative to other wealth transformations, such as the log transformation, that are unable to include values at or below 0 (Friedline, Masa, and Chowa 2015). With the exception of very small values of wealth, the IHS transformed value can be interpreted in the same way as a log transformed dependent variable. That is, the coefficient can be multiplied by one hundred and interpreted in terms of percentage points (Burbidge, Magee, and Robb 1988). In sensitivity analyses, we compare these results with analyses using untransformed wealth and wealth deciles, as well as IHS trans- formed deciles, and find that the results are substantively the same.

\section{Medicaid Eligibility}

To separate possible state Medicaid policy effects from the effects of state-level demographic and economic factors, we follow previous work (Brown, Kowalski, and Lurie 2018; Currie and Gruber 1996; Miller and Wherry 2019) and use simulated prenatal Medicaid eligibility measures. These measures are calculated annually based on state Medicaid eligibility rules in a given year and applied to a national sample of three thousand women from each year (Miller and Wherry 2019).

Given the timing of expansions across states, we limit our NLSY-C analytic sample to the period between 1986 and 2000. Because the simulated eligibility measures estimate statelevel prenatal-infant eligibility, we assign children the simulated Medicaid eligibility value for the mother's state of residence during the year the child was born. Because the NLSY-C interview structure captures children and families biennially in even-numbered years, children born in odd-numbered years are assigned the simulated Medicaid eligibility in their mothers' state of residence for the year prior to birth.

The timing of the state-level Medicaid eligibility measures means that we are examining the effects of Medicaid access on family wealth during the prenatal and infant period. Understanding insurance status and possible wealth effects during this period is important because the early life cycle is a highly sensitive period of brain development. Exposure to healthy behaviors, adequate medical care, and improvements in wealth during this period may especially affect mechanisms responsible for healthy physical and cognitive development (Gluckman and Hanson 2006; Knudsen 2004; Wakschlag et al. 2002). In this vein, the relationship between Medicaid access early in life and children's short and longer-time outcomes is both positive and strong (Currie and Gruber 1996; Miller and Wherry 2019). 


\section{Other Measures}

We include controls from the NLSY-C data, including family income and maternal education, public transfer receipt (at the household or family level), child race-ethnicity, child gender, marital status of parents, and parental employment. At the state level, we use data from the University of Kentucky Poverty Center's State Welfare database, the Current Population Survey, and the Bureau of Labor Statistics to construct measures-we control for the state-year unemployment rate, poverty rate, prevailing minimum wage, share of the population that is black non-Hispanic, share of the population that is Hispanic, and share of the population with a college degree. We also measure the presence of a state Earned Income Tax Credit (EITC) program and the state's percentage of the federal EITC in each year. Finally, we measure states' governance structures with a variable indicating whether the governor is a Democrat.

\section{Approach}

Medicaid eligibility varies by state but depends on family income through eligibility criteria at the state level and, less commonly, wealth via asset tests in six states by $1990 .{ }^{3}$ We use the simulated Medicaid eligibility measures described above to address endogeneity that could influence both family wealth and Medicaid eligibility and therefore bias traditional estimates. Simulated measures also address other methodological issues. First, Medicaid policy changes could encourage families close to the income and wealth eligibility thresholds to alter their behavior. For example, if the eligibility threshold increases, families with more education and financial knowledge could be near the eligibility cutoff and transfer assets to a friend or extended family member to allow them to meet the eligibility requirements. Simulated eligibility addresses potential bias that could be introduced by this type of sorting within states (Biasi 2019). Second, average eligibility among families in a given state varies with state economic measures. For example, recessions may reduce average income and wealth in a state, which would increase the proportion of state residents who are eligible for Medicaid. Because they are based on a national sample of women, simulated eligibility measures are divorced from state-specific changes in economic or demographic changes.

In addition to using simulated eligibility measures, we estimate models with state and year fixed effects to control for state differences correlated with spending and family characteristics (such as labor market structure or level of economic need), and year fixed effects to control for time trends shared across states (such as recession effects). Variation across states in the strength of the labor market and the demographic composition of the population could produce a positive relationship between Medicaid access and economic need that does not reflect true variation in states' investment in Medicaid. Including state fixed effects helps control for these fixed differences across states. In addition, increased economic need during periods of economic downtown is correlated with increases in public-sector investment (Edelstein et al. 2016). Increased state-level investment during recessions may also be correlated with lower wealth. Including year fixed effects helps separate the effects of government investment from the effects of economic need.

The inclusion of state and year fixed effects means that model identification is based on within-state variation in Medicaid eligibility across years, as well as across-state differences in Medicaid generosity in a given year. The key assumption of this approach is that other unmeasured changes in state characteristics did not co-occur with Medicaid eligibility policy changes (Miller and Wherry 2019). For example, if expanded Medicaid eligibility forced states to reduce spending on other programs for the same children affected by increased Medicaid eligibility, our estimates would be biased. Timevarying state controls as well as state and year fixed effects help reduce the possibility that this assumption is violated. Building on this logic, we examine the association between state-level Medicaid access and family wealth using the following model: 


$$
Y_{i s t}=\beta_{0}+\beta_{1} \text { medicaid }_{i s t}+\beta_{2} X_{i s t}+\mu_{s}+\theta_{t}+\varepsilon_{i s t}, \text { (1) }
$$

where, for each child $i$ in state $s$ in year $t$, we model family wealth $(Y)$ - net worth and the other measures of assets and debts described earlier-as a function of state-level simulated prenatal-infant Medicaid eligibility (Medicaid) in the state-year of the child's birth, and the individual and state-level controls $(X)$ described. We measure wealth in the year following a child's birth rather than in the same year. We focus on $\beta_{1}$ to examine the effects of prenatal Medicaid access on children in all families. This step in the analysis will allow us to examine whether higher Medicaid coverage increases the ability of families to save money via increases in assets and reduced debt, or whether Medicaid access does not increase wealth, perhaps because of the need to prioritize short-term expenses.

In the next step of the analysis, we consider heterogeneity in the effects of Medicaid access on family wealth by parental education and child race-ethnicity. The composition of Medicaid participants is heterogeneous across the educational distribution and by race-ethnicity, and wealth also varies dramatically by education and race. We extend equation (1) to estimate stratified models by both parental education and child race-ethnicity, separately. We examine parental education rather than family income to reduce the possibility of endogeneity between Medicaid and family income, which is more variable than education and could be predicted by Medicaid enrollment. If higher statelevel Medicaid access disproportionately affects lower-educated and racial minority families, we would expect to see increases in savings and reductions in debt with increases in Medicaid. Alternatively, if the benefits of Medicaid are largest among the groups more likely to already be in a position to save, we expect to see positive effects of Medicaid increases among higher-educated and nonHispanic white families.

In the analyses described, we use a reduced form estimate rather than an instrumental variable approach because it is more straightforward and easier to interpret, does not require accurate prenatal measures of income and wealth to determine prenatal Medicaid eligibility, incorporates potential spillover effects and potential manipulation around the eligibility threshold, and allows us to examine heterogeneity in the effects of changes in state Medicaid eligibility policy by education and race-ethnicity.

\section{Results}

Table 1 shows descriptive characteristics of the analytic sample. The median family with young children in the analytic sample with children holds $\$ 13,596$ in net worth, with significant variation shown in the standard deviation of $\$ 281,969$. As is well documented in the wealth literature, home value is the largest asset that families possess, with a median value of \$135,550 (Killewald, Pfeffer, and Schachner 2017; Oliver and Shapiro 2006), followed by accounts at $\$ 43,023$. Mortgage is the largest debt held by families in the sample, at $\$ 80,539$. Respondents live in states where an average of 18 percent of pregnant women and infants are eligible to receive Medicaid. Racial diversity in the sample is significant: 21 percent of children are Hispanic, 32 percent are black, and 47 percent are non-Hispanic white. Children are seven years old, on average, at the time of interview. Mothers in the sample are the most likely to hold a high school diploma (38 percent), followed by a college degree (29 percent), and less than a high school diploma (30 percent). Twenty-five percent of the sample receives welfare, and the average annual income is just over $\$ 18,000$.

\section{Is State-Level Medicaid Access \\ Associated with Family Wealth?}

On the association between Medicaid and family wealth, table 2 presents models that predict each dimension of wealth as a function of statelevel Medicaid access, time-invariant and timevarying controls, and state and year fixed effects. For each measure of wealth, we present two models: model 1 includes all time-invariant and time-varying controls; model 2 adds the value of net worth in the year of the child's birth. Model 1 shows that increases in prenatal Medicaid eligibility are significantly associated with the amount of retirement savings, as well as the value of home mortgages (among homeowners). For example, an increase from 0 to 1 
Table 1. Descriptive Characteristics of Sample, NLSY-C 1986-2000

\begin{tabular}{|c|c|c|}
\hline & Mean & $\begin{array}{l}\text { Standard } \\
\text { Deviation }\end{array}$ \\
\hline \multicolumn{3}{|l|}{ Family wealth (median) } \\
\hline Net worth & 13,596 & 281,969 \\
\hline Home value & 135,550 & 158,974 \\
\hline Mortgage & 80,539 & 90,627 \\
\hline Savings & 179.0 & 36,485 \\
\hline Accounts & 43,023 & 103,125 \\
\hline Car value & 12,487 & 18,398 \\
\hline Other debts on home & 0 & 5539 \\
\hline Car debt & 12,002 & 12,722 \\
\hline Percent simulated prenatal Medicaid eligibility & 18.4 & 9.5 \\
\hline Hispanic & 20.9 & 40.6 \\
\hline Black & 32.4 & 46.8 \\
\hline Non-Hispanic white & 46.7 & 49.9 \\
\hline Child age & 6.9 & 4.1 \\
\hline \multicolumn{3}{|l|}{ Mother's educational attainment } \\
\hline Less than high school & 29.7 & 45.7 \\
\hline High school graduate & 38.4 & 48.6 \\
\hline College & 28.6 & 45.2 \\
\hline Girls & 48.7 & 50.0 \\
\hline Receives welfare & 25.4 & 43.5 \\
\hline Married & 60.9 & 48.8 \\
\hline Annual wage (2018 dollars) & 18,038 & 22,625 \\
\hline \multicolumn{3}{|l|}{ State characteristics } \\
\hline Percent unemployed & 5.8 & 1.7 \\
\hline Percent poverty & 13.7 & 3.5 \\
\hline Minimum wage (2018 dollars) & 7.1 & 1.0 \\
\hline Percent white & 73.0 & 13.0 \\
\hline Percent black & 13.9 & 9.4 \\
\hline Percent Hispanic & 9.6 & 11.0 \\
\hline Percent college educated & 17.6 & 8.0 \\
\hline State EITC rate & 1.5 & 6.2 \\
\hline Democratic governor & 0.4 & 0.5 \\
\hline Person years & 36,689 & \\
\hline
\end{tabular}

Source: Author's tabulation based on NLSY-C (Bureau of Labor Statistics, U.S. Department of Labor, and National Institute for Child Health and Human Development 2019). Note: All dollar amounts adjusted to 2018 values.

in the proportion of women and infants eligible for Medicaid (zero to 100 percent eligibility) is associated with an increase of about 234 percent $\left(2.338^{*} 100\right)$ in the value of families' accounts, which include savings, certified deposits, IRAs, and tax-deferred savings plans. Because this is a not a realistic amount of variation in Medicaid access between states, it is useful to provide a range from these data. For reference, among the analytic sample, a standard deviation in simulated prenatal Medicaid eligibility is 0.096 . To put this in context, a one standard deviation difference in eligibility would be the difference between a spending environment like Massachusetts (0.40) and Oklahoma (0.31) in 1992. A two standard deviation 
Table 2. Regression of IHS Wealth Components on Prenatal State Medicaid Eligibility, NLSY-C 1986-2000

\begin{tabular}{|c|c|c|c|c|c|c|}
\hline & $\begin{array}{c}\mathrm{M} 1 \\
\mathrm{~b}\end{array}$ & S.E. & $\begin{array}{c}\mathrm{M} 2 \\
\mathrm{~b}\end{array}$ & S.E. & $\begin{array}{c}\text { Total } \\
\text { Overall } \\
\text { R-Squared }\end{array}$ & $\begin{array}{c}\text { Total } \\
\text { Person } \\
\text { Years }\end{array}$ \\
\hline Net worth & -0.161 & $(0.903)$ & -0.884 & $(0.922)$ & 0.2006 & 36,689 \\
\hline Home value & 0.501 & $(0.342)$ & 0.419 & $(0.355)$ & 0.1234 & 17,242 \\
\hline Mortgage & $1.314^{* *}$ & (0.538) & $1.261^{* *}$ & (0.551) & 0.0719 & 17,242 \\
\hline Savings & -0.124 & $(0.368)$ & -0.283 & $(0.373)$ & 0.3969 & 36,689 \\
\hline Accounts & $2.513^{* * *}$ & $(0.443)$ & $2.338^{* * *}$ & $(0.452)$ & 0.478 & 36,689 \\
\hline Car value & -0.207 & $(0.290)$ & -0.284 & (0.298) & 0.1099 & 29,268 \\
\hline Other debts on home & 0.136 & $(0.179)$ & 0.143 & $(0.181)$ & 0.0093 & 36,689 \\
\hline Car Debt & -0.0404 & $(0.190)$ & -0.0792 & $(0.193)$ & 0.0962 & 15,314 \\
\hline State and year fixed effects & yes & & yes & & & \\
\hline \multicolumn{7}{|c|}{ Z-statistic tests of coefficient equality } \\
\hline Mortgage & -0.07 & & & & & \\
\hline Accounts & -0.28 & & & & & \\
\hline
\end{tabular}

Source: Author's tabulation based on NLSY-C (Bureau of Labor Statistics, U.S. Department of Labor, and National Institute for Child Health and Human Development 2019).

Note: Model 1 controls for all covariates with the exception of pre-birth net worth. Model 2 controls for all covariates, including pre-birth net worth.

${ }^{*} p<.1 ;{ }^{* *} p<.05 ;{ }^{* * *} p<.01$

would be equivalent to the difference between Arkansas (0.34) and Hawaii (0.54) in 1992. In regard to within-state change, a one standard deviation increase in prenatal eligibility would be equivalent to the change in eligibility in California between 1991 (0.40) and 1993 (0.50). A one standard deviation increase in Medicaid eligibility is therefore related to a 22 percent $\left(100^{*}\left(2.338^{*} 0.096\right)\right)$ increase in the amount of wealth held in accounts, and a one standard deviation increase is associated with a 45 percent increase. This association is consistent with the possibility that Medicaid access better allows families to accrue assets via savings.

Model 2 shows that increases in Medicaid access are also related to an increase in the value of home mortgages among those who own a home. This finding could mean that families are able to purchase more expensive homes and build more assets via homeownership than families who live in less generous Medicaid states. The point estimate for home value (among homeowners) is positive but not statistically significant. Panel A of figure 1 plots the relationship between mortgage amount and state-level Medicaid eligibility based on model 2, illustrating the positive relationship.
Panel B of figure 1 paints a similar picture of the association between state Medicaid generosity and the total amount held in accounts.

Overall, analyses for the full sample suggest that increased Medicaid access positively affects family wealth via savings accrued in various types of accounts, as well as via home mortgages. Point estimates for the debt measures examined, including car debt and other home debt, are not significant. Estimates are very similar across models 1 and 2. This finding is unsurprising-given that Medicaid exposure is measured subsequent to pre-birth wealth, Medicaid access should not be highly related to this measure of family wealth.

\section{Variation by Educational Attainment and Race-Ethnicity}

Tables 3 and 4 consider variation in the effects of Medicaid on family wealth by education and race-ethnicity, respectively. Medicaidparticipating families are heterogeneous with respect to their levels of education, with more than one-third of mothers enrolled in Medicaid at the time of the birth of a child having more than a high school education, and about half being Hispanic or non-Hispanic black. Re- 
Figure 1. Margins Plot of Regression of Mortgage Amount and Accounts on Simulated Prenatal Medicaid Eligibility, NLSY-C 1986-2000
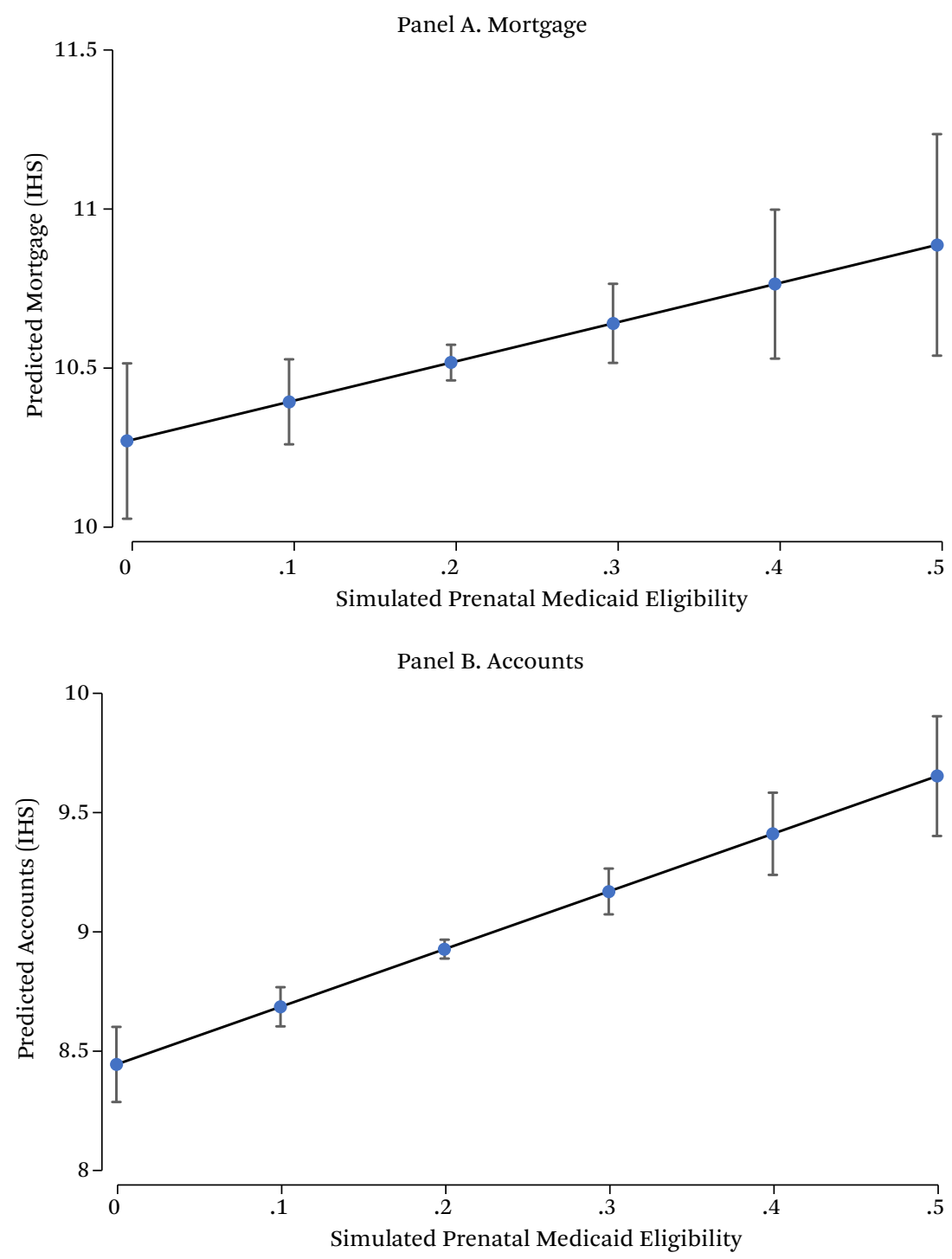

Source: Author's tabulation based on NLSY-C (Bureau of Labor Statistics, U.S. Department of Labor, and National Institute for Child Health and Human Development 2019).

Note: All models control for full set of covariates.

search suggests competing possibilities about the heterogeneous effects of Medicaid on family wealth. If higher state-level Medicaid access disproportionately affects lower-educated and racial minority families, then increases in savings or reductions in debt should accrue to those families with increases in Medicaid. Alternatively, any positive effects of Medicaid increases may be concentrated among higher- educated and non-Hispanic white families if they are in a better position to save for the long term as well as provide for short-term needs.

Table 3 presents the results from the regression of family wealth on state Medicaid access by maternal education. Results are stratified by education, and we compute differences between educational groups using z-statistic tests of coefficient equality. The benefits of in- 
Table 3. Regression of IHS Wealth Components on Prenatal State Medicaid Eligibility by Mother's Education, NLSY-C 1986-2000

\begin{tabular}{|c|c|c|c|c|c|c|}
\hline & \multicolumn{2}{|c|}{$\begin{array}{c}\text { M1 } \\
\text { Less Than } \\
\text { High School }\end{array}$} & \multicolumn{2}{|c|}{$\begin{array}{c}\text { M2 } \\
\text { High School }\end{array}$} & \multicolumn{2}{|c|}{$\begin{array}{c}\text { M3 } \\
\text { College }\end{array}$} \\
\hline & b & SE & b & SE & b & SE \\
\hline Net worth & -11.208 & $(1.811)$ & $-12.654^{*}$ & (1.432) & -0.0479 & (1.349) \\
\hline Home value & 0.313 & (1.698) & 0.868 & $(0.636)$ & 0.00548 & $(0.315)$ \\
\hline Mortgage & 0.696 & (1.658) & 1.239 & (0.994) & 0.955 & $(0.696)$ \\
\hline Savings & -11.015 & $(0.699)$ & -0.722 & $(0.634)$ & -0.00376 & $(0.628)$ \\
\hline Accounts & $-11.427^{* *}$ & $(0.716)$ & 0.236 & (0.788) & $3.646^{* * *}$ & $(0.752)$ \\
\hline Car value & -0.211 & (0.992) & -0.502 & $(0.537)$ & -0.223 & $(0.405)$ \\
\hline Other debts on home & -0.162 & $(0.283)$ & $0.509^{*}$ & $(0.292)$ & -0.181 & $(0.345)$ \\
\hline Car Debt & 0.179 & (0.554) & 0.0615 & (0.323) & -0.405 & $(0.272)$ \\
\hline State and year fixed effects & Yes & & Yes & & Yes & \\
\hline \multicolumn{7}{|c|}{$\begin{array}{l}\text { Z-statistic tests of coefficient } \\
\text { equality (ref. = less than high school) }\end{array}$} \\
\hline Accounts & & - & & $1.56^{*}$ & & $4.89 * * *$ \\
\hline
\end{tabular}

Source: Author's tabulation based on NLSY-C (Bureau of Labor Statistics, U.S. Department of Labor, and National Institute for Child Health and Human Development 2019).

Note: All models control for full set of covariates.

${ }^{*} p<.1 ;{ }^{* *} p<.05 ;{ }^{* * *} p<.01$

creased Medicaid access are significantly greater among higher-educated families. Examining the coefficients for assets held in accounts shows that, among mothers with more than a high school education, the effects of Medicaid are positive and significant. Specifically, a one standard deviation increase in Medicaid eligibility is related to about a 35 percent increase in the amount of wealth held in accounts, among mothers with more than a high school education. This effect is significantly different than among families where the mother has less than a high school education, among whom increases in Medicaid are negatively associated with the value of assets in accounts. The point estimate for account assets is not significant among high school educated families, although families with high school educated mothers accrue significantly more wealth in accounts compared to mothers with less than high school. Figure 2 plots the relationship between state-level Medicaid eligibility and the total amount held in accounts, based on table 3. This figure illustrates the extent to which the most highly educated benefit the most from greater levels of state generosity in this domain.

Table 4 shows the effects of Medicaid access by race-ethnicity. As in table 3, we present separate models by race-ethnicity, computing differences across groups using formal tests of coefficient equality. Examining assets in accounts shows that the positive effects of Medicaid access are driven by non-Hispanic white families, among whom a one standard deviation increase in Medicaid access is related to a 33 percent $\left(100^{*}\left(3.417^{*} 0.096\right)\right)$ increase in account assets. This effect is significantly different from the relationship observed among non-Hispanic blacks and Hispanics, for whom Medicaid has no significant effect on account assets. Examining mortgage amounts (among homeowners) shows that, among non-Hispanic white and non-Hispanic black families, greater Medicaid generosity is associated with more expensive mortgages. Figure 3 plots this relationship and illustrates that although the point estimate is larger for black families, it is not statistically significantly larger than that among white families. 
Figure 2. Coefficients Plot of Predicted Relationship Between Accounts and Simulated Medicaid Eligibility by Mother's Education, NLSY-C 1986-2000

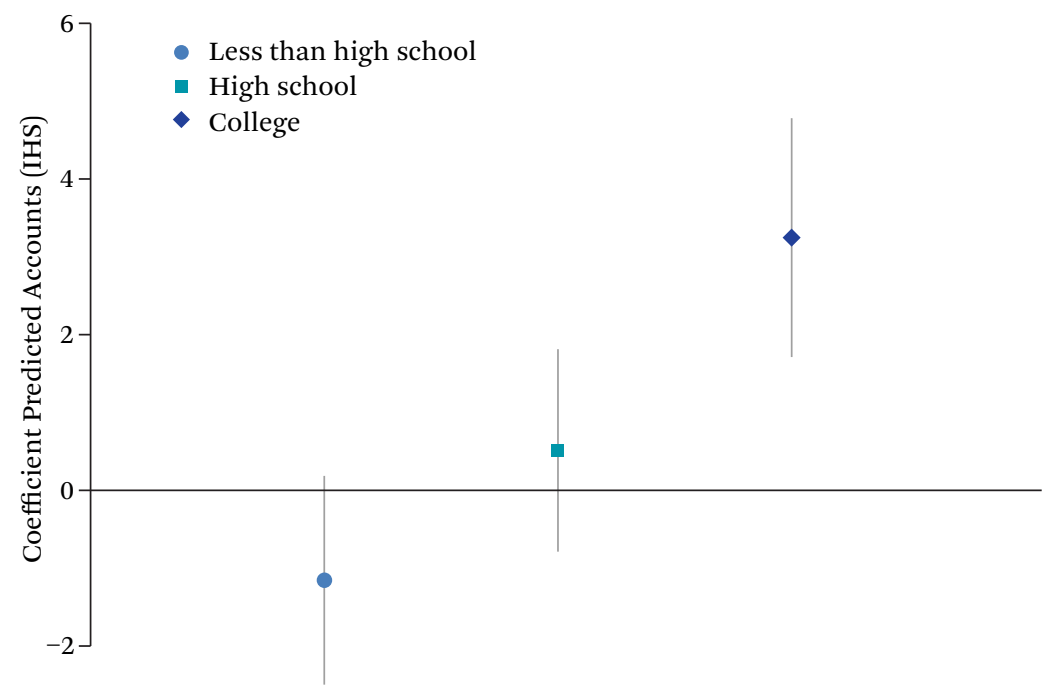

Source: Author's tabulation based on NLSY-C (Bureau of Labor Statistics, U.S. Department of Labor, and National Institute for Child Health and Human Development 2019). Note: All models control for full set of covariates.

Table 4. Regression of IHS Wealth Components on Prenatal State Medicaid Eligibility by Race, NLSY-C $1986-2000$

\begin{tabular}{|c|c|c|c|c|c|c|}
\hline & \multicolumn{2}{|c|}{$\begin{array}{c}\text { M1 } \\
\text { White }\end{array}$} & \multicolumn{2}{|c|}{$\begin{array}{c}\text { M2 } \\
\text { Black }\end{array}$} & \multicolumn{2}{|c|}{$\begin{array}{c}\text { M3 } \\
\text { Hispanic }\end{array}$} \\
\hline & $b$ & SE & $\mathrm{b}$ & SE & $b$ & SE \\
\hline Net worth & -0.638 & (1.115) & 0.0389 & $(1.681)$ & -12.367 & (1.994) \\
\hline Home value & 0.254 & (0.339) & 1.423 & (1.444) & -0.237 & (0.958) \\
\hline Mortgage & $1.646^{* *}$ & $(0.663)$ & $3.921^{* *}$ & $(1.682)$ & -11.555 & $(1.139)$ \\
\hline Savings & 0.478 & (0.531) & $-11.180^{*}$ & $(0.666)$ & $-11.731^{* *}$ & $(0.795)$ \\
\hline Accounts & $3.417^{* * *}$ & (0.694) & 0.705 & $(0.780)$ & -0.311 & $(0.874)$ \\
\hline Car value & -0.391 & (0.299) & 0.114 & (0.933) & -0.0167 & $(0.721)$ \\
\hline Other debts on home & -0.0484 & $(0.301)$ & 0.183 & $(0.236)$ & 0.584 & $(0.375)$ \\
\hline Car debt & -0.180 & $(0.274)$ & -0.177 & $(0.454)$ & 0.0836 & $(0.389)$ \\
\hline State and year fixed effects & Yes & & Yes & & Yes & \\
\hline \multicolumn{7}{|c|}{$\begin{array}{l}\text { Z-statistic tests of coefficient } \\
\text { equality (ref. = white) }\end{array}$} \\
\hline Mortgage & & - & & 1.26 & & $-12.43 * *$ \\
\hline Savings & & - & & $-11.95^{\star}$ & & $-12.31^{* *}$ \\
\hline Accounts & & - & & $-12.60 * * *$ & & $-13.34^{* * *}$ \\
\hline
\end{tabular}

Source: Author's tabulation based on NLSY-C (Bureau of Labor Statistics, U.S. Department of Labor, and National Institute for Child Health and Human Development 2019).

Note: All models control for full set of covariates.

${ }^{*} p<.1 ;{ }^{* *} p<.05 ;{ }^{* * *} p<.01$ 
Figure 3. Coefficients Plot of Predicted Relationship Between Mortgage Amount and Simulated Medicaid Eligibility by Race, NLSY-C 1986-2000

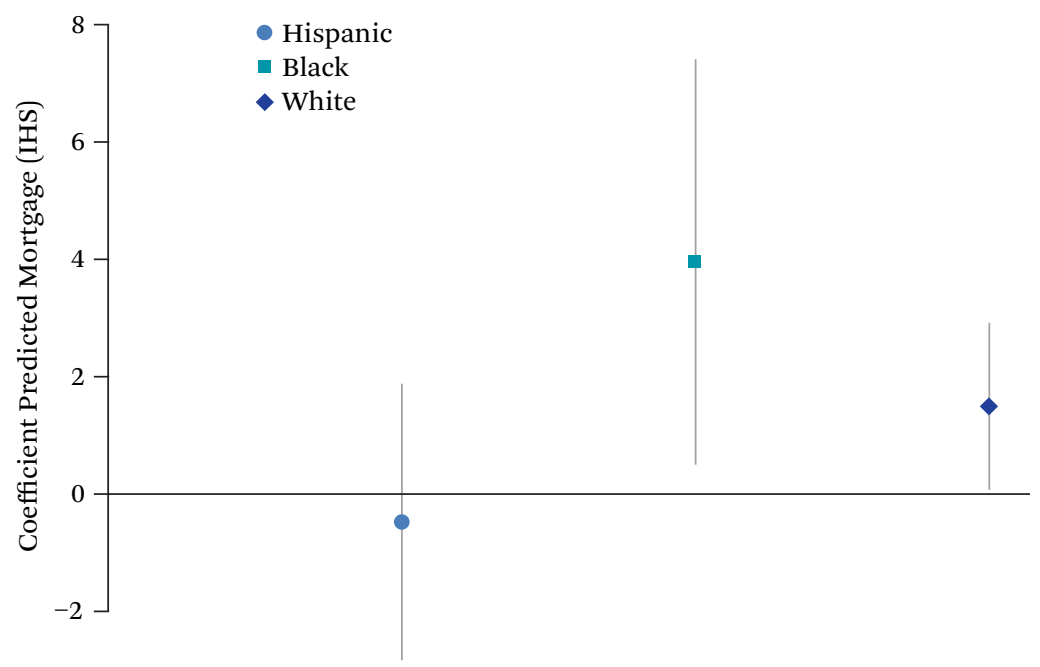

Source: Author's tabulation based on NLSY-C (Bureau of Labor Statistics, U.S. Department of Labor, and National Institute for Child Health and Human Development 2019).

Note: All models control for full set of covariates.

Overall, analyses of the heterogeneous effects of Medicaid access suggest that the positive effects of Medicaid on family wealth are most pronounced among more educated and non-Hispanic white families. The same mechanisms that better allow these families to build wealth may permit them to continue to build wealth with expanded access to health insurance coverage.

\section{DISCUSSION}

Given the little to no evidence on the implications of Medicaid for wealth among families with children, we use NLSY-C and simulated Medicaid eligibility data to examine the effects of expanded prenatal Medicaid eligibility in the 1980 s on family wealth. Simulated Medicaid eligibility addresses potential sorting around the cutoff (Biasi 2019) and state-specific changes in economic or demographic characteristics, which could bias naïve estimates. We find that expanded Medicaid access increased family wealth in the form of savings in various types of accounts and in home mortgages. Medicaid expansion did not significantly change other family debt measures or net worth. An increase of one standard deviation in Medicaid eligibility (equivalent to the difference between Massachusetts and Oklahoma in 1992) is related to a 22 percent increase in the amount of wealth families hold in accounts.

These results suggest Medicaid access can facilitate family wealth building through improvements in savings and investment in home mortgages. Our findings that Medicaid expansion increased the average home mortgage amount but did not increase home value suggests that Medicaid access could help families save enough to qualify for a larger mortgage (or potentially contribute toward a down payment) on a house. Alternatively, Medicaid eligibility may have been one factor considered by mortgage companies in calculating the amount of mortgage for which a family qualifies. If families are more protected from financial shocks due to medical expenses (Gross and Notowidigdo 2011; Slusky and Ginther 2017; Hu et al. 2018; Miller and Wherry 2019), lenders may assign them lower risk values and qualify them for higher mortgage amounts. Medicaid expansion did not translate into increases in total net worth. Instead of uniformly affecting the mix 
of assets and debts that make up net worth, the benefits appear more targeted. Because mortgages are debts, and accounts are assets, increases in both with Medicaid expansion may cancel out to produce no net effect on net worth. In addition, the effects of Medicaid expansion on savings and mortgage amounts that we observe in the short term may help families build higher net worth in the longer term.

Despite aggregate benefits, we find significant differences in the effects of Medicaid expansion by race and maternal education. The positive effects on family wealth among the full sample are driven by benefits for more highly educated and non-Hispanic white families. For example, Medicaid expansion increased account values among mothers with more than a high school education but may have reduced account values among families where the mother has less than a high school education. Similarly, Medicaid expansion increased account assets among non-Hispanic white families but had no effect on account assets among non-Hispanic blacks and Hispanics. Instead, Medicaid expansion increased mortgages among non-Hispanic blacks and reduced savings among non-Hispanic black and Hispanic families. Thus, rather than increasing wealth among less educated and nonwhite families, Medicaid expansion facilitated wealth development more among higher-educated and nonHispanic white families. One possible explanation for these findings is that more educated and non-Hispanic white families were more likely to become newly eligible for Medicaid because the eligibility of the poorest families did not change with expansion. For example, families who gained Medicaid access when eligibility was raised to 133 percent of the poverty line were less likely to be headed by women or blacks than when eligibility was capped at 100 percent-although families in the slightly higher income group were also less likely than the lowest-income families to take up the benefits for which they were newly eligible (Card and Shore-Sheppard 2004). In this case, it may not be surprising that the benefits of expansion would be concentrated among more advantaged families who were less prevalent in the Medicaid-eligible population prior to expansion.
Alternatively, expanded access to health insurance coverage may allow families with racial and educational advantages to capitalize on those advantages and build more wealth than others without those advantages. If the benefits of Medicaid expansion were concentrated among more educated and non-Hispanic white families, then raising income and asset thresholds for Medicaid eligibility may have increased education and racial-ethnic inequality in wealth among families with children, rather than playing an equalizing role. Future research could examine whether the wealth effects of expansion were concentrated at particular points in the distribution, and what the implications of changes are for commonly used indices of inequality such as the Gini coefficient and Theil index.

Our study has several limitations. First, we measure family wealth in the year after pregnancy and birth. Families may be in flux during pregnancy, particularly those with less educated and nonwhite mothers. Our estimates may therefore underestimate effects on wealth (due to measurement error and attenuation bias) and could underestimate effects more among nonwhite and less educated mothers. Future research could examine long-term effects on family wealth. Second, our analyses rely on survey data rather than administrative data. However, wealth data include substantial error (Juster and Smith 1997) and the NLSY-C data we use include measures of a rich array of assets, in addition to capturing a sample of young families. Third, we provide intent-totreat estimates to avoid endogeneity concerns about selection into Medicaid enrollment when using treatment-on-the-treated estimates (Freedman 2006). Future research could provide treatment-on-the-treated estimates and identify specific mechanisms for effects of Medicaid expansion on family wealth.

Our analytic strategy leverages within-state variation in Medicaid eligibility over time and across-state differences in Medicaid generosity in a given year. A strength of our strategy is that it addresses changes over time that may affect families' ability to save in all states, as well as stable differences between states that may be related to state spending or families' ability to build wealth. For example, our reliance on 
within-state variation accounts for a potential correlation between state-level wealth and Medicaid generosity. Our findings rely on the assumption that other state-specific changes with implications for family wealth did not cooccur with changes in Medicaid eligibility (Miller and Wherry 2019). For example, our estimates would likely be downwardly biased if states that increased Medicaid eligibility had less money to spend on other programs that would have benefited the same families who gained Medicaid eligibility. Alternatively, our estimates would also be biased if states with rising family income are more likely to expand Medicaid eligibility and families in those states are able to save more over time. We include time-varying state controls, in addition to state and year fixed effects, to rule out multiple potential state characteristics that could violate our assumption. However, future work could examine whether or to what extent state Medicaid policy changes or family wealth depend on trends in state characteristics.

Overall, our analyses contribute to knowledge about the implications of Medicaid for family wealth. Our results suggest that Medicaid expansion increased wealth among fami- lies with children. However, heterogeneous effects reveal that the benefits of Medicaid expansion accrued to white families and those with more education. Contrary to evidence that the benefits of progressive policies that provide transfers to low-resource families tend to be larger among the most disadvantaged participants (Goodman-Bacon 2018; Meyer 2010), we find that benefits are larger among more advantaged families. This suggests that the relative advantages of more educated, white families render them better able to increase savings with Medicaid access. Evidence that Medicaid increased wealth inequality could reflect greater income instability among lower-SES adults (Hannagan and Morduch 2015; Kalleberg, Reskin, and Hudson 2000; Pew Charitable Trusts 2017) and greater economic returns to savings among families with existing advantages (Shapiro, Meschede, and Osoro 2013). Our results suggest that Medicaid expansion can help families build wealth, but its benefits are unequal. Efforts to improve wealth among black and Hispanic families and those with low education could pair Medicaid eligibility with targeted cash transfers or other supports.

Figure A1. Variation in Family Net Worth by Tercile of State-Level Medicaid Generosity

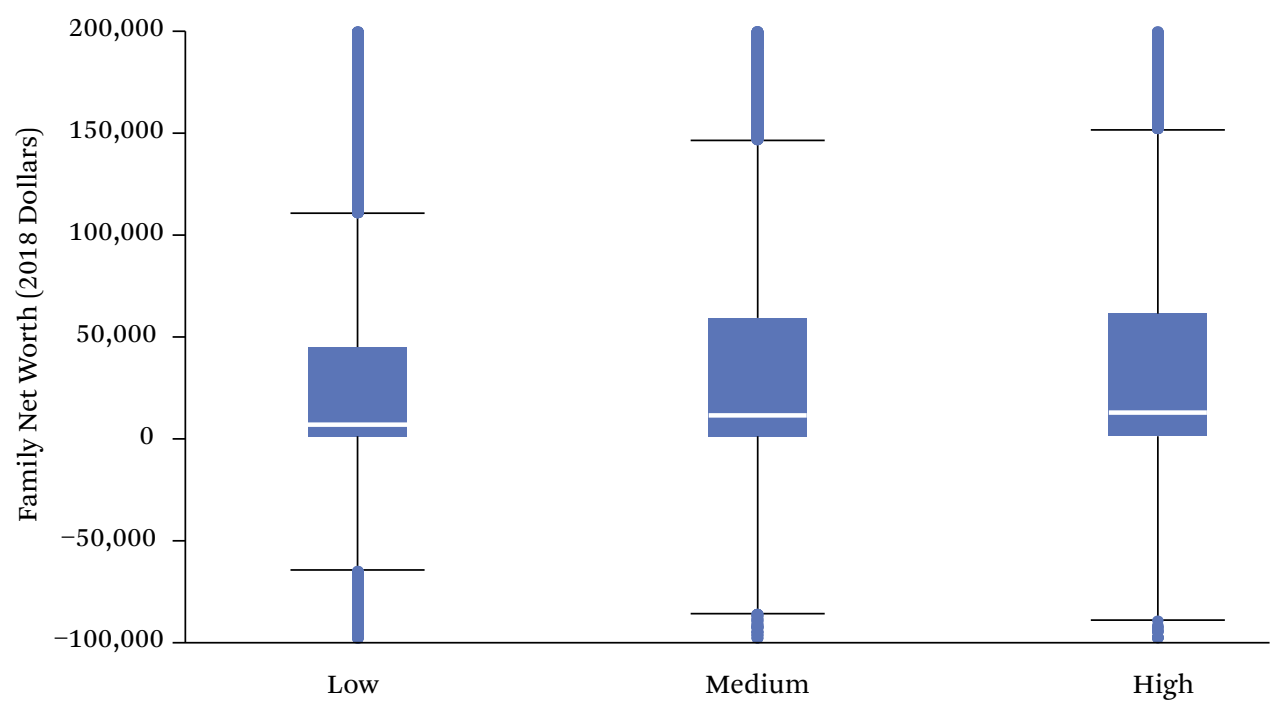

Source: Author's tabulation based on NLSY-C (Bureau of Labor Statistics, U.S. Department of Labor, and National Institute for Child Health and Human Development 2019).

Note: All models control for full set of covariates. 


\section{REFERENCES}

Biasi, Barbara. 2019. “School Finance Equalization Increases Intergenerational Mobility: Evidence from a Simulated-Instruments Approach." NBER working paper no. 25600. Cambridge, Mass.: National Bureau of Economic Research. Accessed December 8, 2020. https://www.nber.org/papers /w25600.

Brown, David W., Amanda E. Kowalski, and Ithai Z. Lurie. 2018. “Long-Term Impacts of Childhood Medicaid Expansions on Outcomes in Adulthood." NBER working paper no. 20835. Cambridge, Mass.: National Bureau of Economic Research. Accessed December 8, 2020. http:// www.econ.yale.edu/ ak669/medicaid.latest .draft.pdf.

Burbidge, John B., Lonnie Magee, and A. Leslie Robb. 1988. "Alternative Transformations to Handle Extreme Values of the Dependent Variable." Journal of the American Statistical Association 83(401): 123-27.

Bureau of Labor Statistics, U.S. Department of Labor, and National Institute for Child Health and Human Development. 2019. Children of the NLSY79, 1979-2016 data set. Columbus: Center for Human Resource Research, The Ohio State University.

Card, David, and Lara D. Shore-Sheppard. 2004. “Using Discontinuous Eligibility Rules to Identify the Effects of the Federal Medicaid Expansions on Low-Income Children." Review of Economics and Statistics 86(3): 752-66.

Collins, William J., and Robert A. Margo. 2001. "Race and Home Ownership: A Century-Long View." Explorations in Economic History 38(1): 68-92.

Conley, Dalton. 1999. Living in the Red: Race Wealth, and Social Policy in America. Berkeley: University of California Press.

Coyer, Christine, and Genevieve M. Kenney. 2013.

"The Composition of Children Enrolled in Medicaid and CHIP: Variation over Time and by Race and Ethnicity." Low Income Working Families paper no. 22. Washington, D.C.: Urban Institute. Accessed December 8, 2020. https://www.urban .org/sites/default/files/publication/32686 /412783-The-Composition-of-Children-Enrolled -in-Medicaid-and-CHIP-Variation-over-Time-and -by-Race-and-Ethnicity.PDF.

Currie, Janet. 2005. "Health Disparities and Gaps in School Readiness." The Future of Children: 15(1):
117-38. Accessed December 8, 2020. https://

files.eric.ed.gov/fulltext/EJ795844.pdf.

Currie, Janet, and Jonathan Gruber. 1996. "Health Insurance Eligibility, Utilization of Medical Care, and Child Health." Quarterly Journal of Economics 111(2): 431-66.

Cutler, David M., and Jonathan Gruber. 1996. "Does Public Insurance Crowd Out Private Insurance?" Quarterly Journal of Economics 111(2): 391-430.

Dettling, Lisa J., Joanne W. Hsu, Lindsay Jacobs, Kevin B. Moore, and Jeffrey P. Thompson. 2017. “Recent Trends in Wealth-Holding by Race and Ethnicity: Evidence from the Survey of Consumer Finances." FEDS Notes no. 2083. Washington, D.C.: Board of Governors of the Federal Reserve System. Accessed December 8, 2020. https:// www.federalreserve.gov/econres/notes/feds -notes/recent-trends-in-wealth-holding-by-race -and-ethnicity-evidence-from-the-survey-of -consumer-finances-20170927.htm.

Dubay, Lisa, and Genevieve M. Kenney. 1997. “Lessons from the Medicaid Expansions for Children and Pregnant Women: Implications for Current Policy." Testimony Before the House Committee on Ways and Means, Subcommittee on Health. Washington, D.C.: Urban Institute. Accessed December 8, 2020. https://www.urban.org/sites /default/files/publication/67161/900284 -Lessons-from-the-Medicaid-Expansions-For -Children-and-Pregnant-Women-Implications -For-Current-Policy.pdf.

Du Bois, W. E. B. 1935. Black Reconstruction in America: An Essay Toward a History of the Part Which Black Folk Played in the Attempt to Reconstruct Democracy in America, 1860-1880. New York: Oxford University Press.

Edelstein, Sara, Heather Hahn, Julia Isaacs, Ellen Steele, and C. Eugene Steuerle. 2016. “Kids' Share 2016: Federal Expenditures on Children Through 2015 and Future Projections." Washington, D.C.: Urban Institute. Accessed December 8, 2020. http://www.urban.org/sites/default/files /publication/84301/2000934-Kids-Share-2016 -Federal-Expenditures-on-Children-through-2015 -and-Future-Projections.pdf.

Elliott, William, III, Mesmin Destin, and Terri Friedline. 2011. "Taking Stock of Ten Years of Research on the Relationship Between Assets and Children's Educational Outcomes: Implications for Theory, Policy and Intervention." Children and Youth Services Review 33(11): 2312-28. 
Faber, Jacob William. 2018. “Segregation and the Geography of Creditworthiness: Racial Inequality in a Recovered Mortgage Market." Housing Policy Debate 28(2): 215-47.

Finkelstein, Amy, Sarah Taubman, Bill Wright, Mira Bernstein, Jonathan Gruber, Joseph P. Newhouse, Heidi Allen, Katherine Baicker, and Oregon Health Study Group. 2012. “The Oregon Health Insurance Experiment: Evidence from the First Year." Quarterly Journal of Economics 127(3): 1057-106.

Freedman, David A. 2006. "Statistical Models for Causation: What Inferential Leverage Do They Provide?" Evaluation Review 30(6): 691-713.

Freund, David M. P. 2007. Colored Property: State Policy and White Racial Politics in Suburban America. Chicago: University of Chicago Press.

Friedline, Terri, Rainier D. Masa, and Gina A. N. Chowa. 2015. "Transforming Wealth: Using the Inverse Hyperbolic Sine (IHS) and Splines to Predict Youth's Math Achievement." Social Science Research 49 (January): 264-87.

Gibson-Davis, Christina M., and Christine Percheski. 2018. “Children and the Elderly: Wealth Inequality Among America's Dependents." Demography 55(3): 1009-32.

Gluckman, Petter D., and Mark A. Hanson. 2006. "The Developmental Origins of Health and Disease." In Early Life Origins of Health and Disease, edited by Julie A. Owens. Boston, Mass.: Springer.

Goodman-Bacon, Andrew. 2018. “Public Insurance and Mortality: Evidence from Medicaid Implementation." Journal of Political Economy 126(1): 216-62.

Government Accountability Office. 1987. “Medicaid: Interstates Variations in Benefits and Expenditures." Briefing report to the Honorable Daniel Patrick Moynihan, United States Senate. Ann Arbor: University of Michigan Library.

Gross, Tal, and Matthew J. Notowidigdo. 2011. “Health Insurance and the Consumer Bankruptcy Decision: Evidence from Expansions of Medicaid." Journal of Public Economics 95 (7-8): 76778.

Gruber, Jonathan, and Aaron Yelowitz. 1999. "Public Health Insurance and Private Savings." Journal of Political Economy 107(6): 1249-74.

Hannagan, Anthony, and Jonathan Morduch. 2015. "Income Gains and Month-to-Month Income Volatility: Household Evidence from the US Finan- cial Diaries." SSRN Electronic Journal. DOI: 10.2139/ssrn.2659883. Accessed December 8, 2020. https://papers.ssrn.com/sol3/papers.cfm ?abstract_id=2659883.

Hartog, Joop, and Hessel Oosterbeek. 1998. "Health, Wealth and Happiness: Why Pursue a Higher Education?" Economics of Education Review 17(3): 245-56.

Hu, Luojia, Robert Kaestner, Bhashkar Mazumder, Sarah Miller, and Ashley Wong. 2018. “The Effect of the Affordable Care Act Medicaid Expansions on Financial Wellbeing." Journal of Public Economics 163 (July): 99-112.

Isaacs, Julia, and Sara Edelstein. 2017. “Unequal Playing Field: State Differences in Spending on Children in 2013." Washington, D.C.: Urban Institute. Accessed December 8, 2020. http://www .urban.org/sites/default/files/publication/89881 /unequal_playing_field_0.pdf.

Juster, F. Thomas, and James P. Smith. 1997. “Improving the Quality of Economic Data: Lessons from HRS and AHEAD." Journal of the American Statistical Association 92(440): 1268-78.

Kalleberg, Arne L., Barbara F. Reskin, and Ken Hudson. 2000. "Bad Jobs in America: Standard and Nonstandard Employment Relations and Job Quality in the United States." American Sociological Review 65(2): 256-78.

Killewald, Alexandra, and Brielle Bryan. 2016. “Does Your Home Make You Wealthy?" RSF: The Russell Sage Foundation Journal of the Social Sciences 2(6): 110-28. DOI: 10.7758/RSF.2016 .2.6.06

Killewald, Alexandra, Fabian T. Pfeffer, and Jared N. Schachner. 2017. "Wealth Inequality and Accumulation." Annual Review of Sociology 43(1): 379-404.

Knudsen, Eric I. 2004. "Sensitive Periods in the Development of the Brain and Behavior." Journal of Cognitive Neuroscience 16(8): 1412-25.

Leininger, Lindsey, Helen Levy, and Diane Schanzenbach. 2010 "Consequences of SCHIP Expansions for Household Well-being." Forum for Health Economics \& Policy 13(1): 1-30.

Lloyd, Patricia C., Anne K. Driscoll, Alan E. Simon, and Jennifer D. Parker. 2018. “Use of the National Health Interview Survey Linked to Medicaid Analytic eXtract Data to Identify Children with Medicaid-Covered Births." National Health Statistics Reports no. 109, April 2. Washington: U.S. Department of Health and Human Services, Cen- 
ters for Disease Control and Prevention. Accessed December 8, 2020. https://www.cdc.gov /nchs/data/nhsr/nhsr109.pdf.

Meyer, Bruce D. 2010. “The Effects of the Earned Income Tax Credit and Recent Reforms." Tax Policy and the Economy 24(1): 153-80.

Miller, Sarah, and Laura R. Wherry. 2019. "The LongTerm Effects of Early Life Medicaid Coverage." Journal of Human Resources 54(3): 785-824.

National Governors' Association. 1990. “State Medicaid Coverage of Pregnant Women and Children-January 1990." Washington, D.C.: NGA Center for Policy Research.

—. 1992. "State Medicaid Coverage of Pregnant Women and Children-July 1992." Washington, D.C.: NGA Center for Policy Research.

National Low Income Housing Coalition. 2020. The Gap: A Shortage of Affordable Rental Homes. Washington, D.C.: National Low Income Housing Coalition.

Oliver, Melvin L., and Thomas M. Shapiro. 2006. Black Wealth, White Wealth: A New Perspective on Racial Inequality, 10th anniversary ed. New York: Routledge.

Orr, Amy J. 2003. “Black-White Differences in Achievement: The Importance of Wealth." Sociology of Education 76(4): 281-304.

Pew Charitable Trusts. 2017. “How Income Volatility Interacts With American Families' Financial Security." Issue Brief. Washington, D.C.: Pew Charitable Trusts. Accessed December 8, 2020. https://www.pewtrusts.org/-/media/assets /2017/03/incomevolatility_and_financial security.pdf.

Pfeffer, Fabian T. 2018. “Growing Wealth Gaps in Education." Demography 55(3): 1033-68.

Pfeffer, Fabian T., Sheldon Danziger, and Robert F. Schoeni. 2013. “Wealth Disparities Before and After the Great Recession." Annals of the American Academy of Political and Social Science 650(1): 98-123.

Quillian, Lincoln, John J. Lee, and Brandon Honoré. 2020. "Racial Discrimination in the U.S. Housing and Mortgage Lending Markets: A Quantitative
Review of Trends, 1976-2016." Race and Social Problems 12(1): 13-28.

Saez, Emmanuel, and Gabriel Zucman. 2016. "Wealth Inequality in the United States Since 1913: Evidence from Capitalized Income Tax Data." Quarterly Journal of Economics 131(2): 519-78.

Semyonov, Moshe, and Noah Lewin-Epstein. 2013. “Ways to Richness: Determination of Household Wealth in 16 Countries." European Sociological Review 29(6): 1134-48.

Shaefer, H. Luke, Colleen M. Grogan, and Harold A. Pollack. 2011. “Transitions from Private to Public Health Coverage Among Children: Estimating Effects on Out-of-Pocket Medical Costs and Health Insurance Premium Costs." Health Services Research 46(3): 840-58.

Shapiro, Thomas, Tatjana Meschede, and Sam Osoro. 2013. "The Roots of the Widening Racial Wealth Gap: Explaining the Black-White Economic Divide." Research and Policy Brief, February. Waltham, Mass.: Brandeis University, Institute on Assets and Social Policy. Accessed December 9, 2020. https://heller.brandeis.edu /iasp/pdfs/racial-wealth-equity/racial-wealth -gap/roots-widening-racial-wealth-gap.pdf.

Slusky, David, and Donna Ginther. 2017. “Did Medicaid Expansion Reduce Medical Divorce?" NBER working paper no. w23139. Cambridge, Mass.: National Bureau of Economic Research.

Stone, Chad, Danilo Trisi, Arloc Sherman, and Jennifer Beltrán. 2020. A Guide to Statistics on Historical Trends in Income Inequality. Washington, D.C.: Center on Budget and Policy Priorities.

Taylor, Keeanga-Yamahtta. 2019. Race for Profit: How Banks and the Real Estate Industry Undermined Black Homeownership. Chapel Hill: University of North Carolina Press.

Wakschlag, Lauren S., Kate E. Pickett, Edwin Cook Jr., Neal L. Benowitz, and Bennett L. Leventhal. 2002. "Maternal Smoking During Pregnancy and Severe Antisocial Behavior in Offspring: A Review." American Journal of Public Health 92(6): 966-74. 